\title{
DNA-marker based identification of the RPV3 gene determining downy mildew resistance in grapevines
}

\author{
E.T. Ilnitskaya ${ }^{1} \otimes$, M.V. Makarkina ${ }^{1}$, S.V. Tokmakov ${ }^{1}$, L.G. Naumova ${ }^{2}$ \\ ${ }^{1}$ North-Caucasian Federal Scientific Center of Horticulture, Viticulture, Winemaking, Krasnodar, Russia
${ }^{2}$ All-Russian Research Institute of Viticulture and Winemaking named after Ya.I. Potapenko, Novocherkassk, Russia
}

Downy mildew is one of the most common fungal diseases of the vine, caused by Plasmopara viticola. An effective way to control the spread of the pathogen is to cultivate resistant varieties. Cultivars of Vitis vinifera, being the basis of high-quality viticulture, practically do not possess genetic resistance to $P$. viticola, so screening for resistance donors is an important stage in breeding. One of the major resistance loci to downy mildew, the Rpv3 gene, was identified in the genotype of a complex interspecific hybrid of grapes Bianca. Later, it was found that this gene had seven haplotypes of resistance inherited from North American grape species, and that it was possible to identify the allelic status of the gene using DNA-markers UDV305, UDV737. However, only two haplotypes can be combined in one diploid form. To determine the Rpv3 gene in the grape gene pool we, using these markers, studied 35 different genotypes of grapevines, most of which are interspecies cultivars. Three varieties with known allelic status of the Rpv3 gene (Dunavski lazur, Noah, Seyve Villard 12-375) were included in the study as reference genotypes. The genotypes were studied through polymerase chain reaction with separation of amplification products by capillary electrophoresis in automatic genetic analyzer ABI Prism 3130. In the studied grape cultivars DNA marker analysis indentified the Rpv3 gene in sixteen genotypes of interspecific origin, including haplotype $R p v 3^{299-279}$ found in twelve varieties, Rpv $3^{321-312}$ - in three, and haplotype $R p v 3^{\text {null-271 }}$ - in one variety. Seyve Villard 12-375 turned out to be the donor of resistance gene in the most of the genotypes carrying Rpv3 in this study. The obtained data can be useful in selection of mildew resistant grape varieties and screening for hybridization pairs.

Key words: grapevine; resistance to downy mildew; gene Rpv3; haplotype; DNA-markers; interspecific hybrids.

\section{HOW TO CITE THIS ARTICLE:}

Ilnitskaya E.T., Makarkina M.V., Tokmakov S.V., Naumova L.G. DNA-marker based identification of the RPV3 gene determining downy mildew resistance in grapevines. Vavilovskii Zhurnal Genetiki i Selektsii=Vavilov Journal of Genetics and Breeding. 2018;22(6):703-707. DOI 10.18699/VJ18.413

Received 12.02.2018

Accepted for publication 24.06.2018

(c) AUTHORS, 2018

\section{ДНК-диагностика гена RPV3, определяющего устойчивость винограда к возбудителю милдью}

\author{
Е.Т. ИАьницкая ${ }^{1} \otimes$, М.В. Макаркина ${ }^{1}$, С.В. Токмаков ${ }^{1}$, \\ А.Г. Наумова ${ }^{2}$ \\ ${ }^{1}$ Северо-Кавказский федеральный научный центр садоводства, \\ виноградарства, виноделия, Краснодар, Россия \\ 2 Всероссийский научно-исследовательский институт виноградарства \\ и виноделия им. Я.И. Потапенко, Новочеркасск, Россия
}

Милдью - одно из наиболее распространенных грибных заболеваний виноградной лозы, вызываемое Plasmopara viticola. Эффективным способом контроля распространения патогена является возделывание устойчивых сортов. Сорта Vitis vinifera, считаясь основой высококачественного виноградарства, практически не обладают генетической устойчивостью к P. viticola. Поиск доноров устойчивости важный этап в селекции. Один из крупных локусов устойчивости к милдью, ген Rpv3, впервые был определен в генотипе сложного межвидового гибрида винограда Бианка. Позже было установлено, что этот ген имеет семь гаплотипов устойчивости, наследуемых от североамериканских видов винограда; идентифицировать аллельное состояние гена можно с помощью ДНК-маркеров UDV305 и UDV737. В одной диплоидной форме могут быть объединены только два гаплотипа. С целью определения гена $R p v 3$ в генофонде винограда с использованием указанных маркеров нами проведено изучение 35 генотипов различного происхождения, большинство из которых - межвидовые сорта. Три сорта, аллельное состояние гена Rpv3 в которых известно, были включены в исследование в качестве референсных генотипов: Дунавски лазур, Ноа, Сейв Виллар 12-375. Работа проведена методом полимеразной цепной реакции с разделением продуктов амплификации методом капиллярного электрофореза при использовании автоматического генетического анализатора ABI Prism 3130. В исследуемой выборке сортов винограда, согласно данным проведенного ДНК-маркерного анализа, ген Rpv3 определен впервые в 16 генотипах межвидового происхождения, в том числе в ДНК 12 сортов идентифицирован гаплотип Rpv3299-279, в трех $R p v 3^{321-312}$, в одном сорте выявлен гаплотип Rpv3 $3^{\text {null-271 }}$. В большинстве идентифицированных нами генотипов, несущих Rpv3, донором гена является Сейв Виллар 12-375. Сорта винограда, в которых были идентифицированы гаплотипы Rpv3, определяющие устойчивость, характеризуются высоким или повышенным уровнем устойчивости к милдью. Полученные данные могут быть полезны в селекции устойчивых сортов винограда при подборе пар для гибридизации.

Ключевые слова: виноград; устойчивость к милдью; ген Rpv3; гаплотип; ДНК-маркеры; межвидовые гибриды. 
$\mathrm{D}$ owny mildew is one of the most widespread and destructive fungal diseases in the grapevine, caused by oomycete Plasmopara viticola Berl. et de Toni. The pathogen affects only the vine developing in its every green organ: leafs, shoots, inflorescences, grapes and tendrils. In favorable conditions such as warm temperature and excessive humidity, mildew may cause harvest failure from 50 to $100 \%$ in different grape varieties (Talash, 2010).

Cultivation of resistant varieties remains one of the most effective methods of disease control that allows one to reduce the amount of pesticide sprayings, and in this way improves the ampelocenosis, food safety and harvest of grapes.

The success of such cultivation is rooted into the genetic diversity of a culture and in many ways is determined by the level of knowledge about an accumulated genetic pool. Identification of the genotypes to serve as resistance donors has been one the topical issues in the science of selection. Being the foundation of high-quality vine growing cultivars Vitis vinifera have almost no genetic resistance to Plasmopara viticola, while downy mildew - resistant genotypes belong to vine species from North America and Asia ( $V$. aestivalis, $V$. berlandieri, $V$. cinerea, $V$. riparia, $V$. rupestris, etc.) as well as to Muscadinia rotundifolia (Alleweldt et al., 1988; Wan et al., 2007).

Molecular genetic methods are widely applied these days for identification and mapping of valuable genes, gene- pool diversity analysis, and DNA-marker selection in different breeding programs. The methods have made it possible to determine around 20 mildew-resistant loci in a vine genome (http://www.vivc.de). Many of them have been mapped and given names with their linked DNA-markers identified including those appropriate for DNA marker selection (Eibach et al., 2007; Di Gaspero et al., 2012; Schwander et al., 2012; Venuti et al., 2013; Zini et al., 2014; Ochssner et al., 2016).

The Rpv3 gene, one of the major loci of resistance, was detected for the first time and mapped at chromosome 18 in the genotype of a complex interspecies hybrid Bianca carrying the geneplasm of $V$. vinifera, $V$. labrusca, $V$. rupestris, $V$. berlandieri, $V$. lincecumii (Bellin et al., 2009). Later, in the course of a large-scale study into the North American species and varieties carrying $R p v 3$, one detected the seven conservative haplotypes of this gene responsible for mildew resistance (Di Gaspero et al., 2012). As the mentioned haplotypes were not found in $V$. vinifera, the authors came to the conclusion that $R p v 3$ could be found in the varieties, whose pedigree had several North American species. The valuable haplotypes localize in a single locus, that is why in case of traditional breeding, only two haplotypes can be combined in a single diploid cell.

The performed studied have resulted in determination of tightly linked flanking microsatellite markers to identify such Rpv3 gene haplotypes as UDV305 and UDV737 (Di Gaspero et al., 2012). The resistant haplotypes of the Rpv3 gene corresponds to the following allele states of the abovementioned loci (UDV305, UDV737, respectively): $R p v 3^{299-279}$ (inherited from $V$. rupestris), Rpv3null-297 (V. rupestris or $V$. lincecumii), Rpv3321-312 (V. labrusca or V. riparia), Rpv $3^{\text {null-271 }}$ (V. labrusca or V. riparia), Rpv $3^{361-299}$ (V. rupestris), Rpv $3^{299-314}$ (V.rupestris), Rpv $3^{\text {null-287 }}$ (V. rupestris or $V$. labrusca). G. Di Gaspero at al. have studied more than 200 grapevine varieties to determine their genotypes and stable Rpv3-bearing haplotypes, so their data can be used in screening for hybridization pairs in breeding of downy mildew-resistant cultivars.

The objective of the presented study was using DNAmarker analysis for identification of the allele state of the $R p v 3$ gene in different vine cultivars, and comparison of the obtained data against the genotype pedigree.

\section{Materials and methods}

The study covered 35 grapevine cultivars from the gene pools of the Anapa ampelographic collection (Anapa) and the collection of Ya.I. Potapenko Research Institute of Viticulture and Winemaking (Novocherkassk). Most of the studied cultivars were interspecies hybrids, whose parents were North American vine varieties and, based on analysis of their pedigree, could carry the resistant haplotypes of the Rpv3 gene. In the geneplasm of the studied cultivars - potential carriers of the studied gene - were present $V$. riparia, $V$. labrusca, $V$. aestivalis, $V$. rupestris, $V$. berlandieri, $V$. lincecumii. The study also covered a number of genotypes that should have no Rpv3 gene such as Vitis vinifera and its hybrids with $V$. amurensis.

The vines' DNA was extracted from leaves using the CTAB method (Rogers, Bendich, 1985). The genotypes were determined using polymerase chain reaction (PCR) and the DNAmarkers recommended for identification of the alleles of the Rpv3 gene (Di Gaspero et al., 2012). PCR was performed in a finite volume of $25 \mu \mathrm{l}$ following the standard protocol and using the Sintol reagent kit (Moscow, Russia). DNA amplification was performed in Eppendorf MasterCycler Gradient Thermal Cycler (Germany) with the following protocol for every DNA-marker: 5 minutes at $95^{\circ} \mathrm{C}$ for initial denaturation followed by 35 cycles $\left(10\right.$ seconds for denaturation at $95^{\circ} \mathrm{C}$, 30 seconds for annealing the primers at $55^{\circ} \mathrm{C}, 30$ seconds for synthesis at $72{ }^{\circ} \mathrm{C}$, and 3 minutes for the last cycle of synthesis at $72{ }^{\circ} \mathrm{C}$ ). The reaction products were separated using capillary electrophoresis, and the size of the amplified fragments was estimated with the ABI Prism 3130 automatic genetic analyzer using software packages GeneMapper and PeakScanner. The DNA of the Dunavski lazur, Seyve Villard 12-375 and Noah varieties with known allele sizes for the studied loci (Di Gaspero et al., 2012) were used as controls to specify the sizes of the amplified fragments.

The molecular genetic study was carried out using the equipment provided by Shared Equipment Center "Genomic and Postgenomic Technologies" of North-Caucasian Federal Scientific Center of Horticulture, Viticulture, Winemaking.

\section{Results and discussion}

The performed study determined the allele state of downy mildew-resistant gene Rpv3 in the genotypes of 35 vine cultivars (Table). The gene's resistant haplotypes were identified in 19 varieties: Dunavsky lazur, Noa, Seyve Villard 12-375, Dekabrskiy, Dunavska gymza, Original, Talisman, Kutuzovskiy, Kodryanka, Rusbol, Storgoziya, R65, Kishmish 342, Srebrostrui, VIII 2 -2-48, Armalaga, Poliuks, Podarok Magaracha, Melody (Figure).

In the studied sample haplotype $R p v 3^{299-279}$ occurred more often than others: it was detected in 14 genotypes (see Table). 
In 12 cultivars this haplotype was indentified for the first time.

Haplotype Rpv $3^{321-312}$ was for the first time identified in three cultivars: Armalaga, Poliuks and Podarok Magaracha. DNA-marker analysis identified hyplotype $R p v 3^{\text {null-271 }}$ only in the melody species. The Noah variety that we used as one of the reference genotypes, also carried $R p v 3^{321-312}$ and Rpv3 $3^{\text {null-271. }}$.
According to the published data, haplotype $R p v 3^{299-279}$ we identified in cultivars Dekabrskiy, Dunavska gymza, Original, Talisman, Kutuzovskiy, Kodryanka, Rusbol, Storgoziya, R65, Kishmish 342, Srebrostruy, VIII $2-2-48$, is inherited from the geneplasm of $V$. rupestris. In the analyzed sample of grapevine cultivars six genotypes carrying $R p v 3^{299-279}$ out of twelve inherited the resistant allele directly from their parent variety

Results of analysis of vine genotypes of different origin for the SSR loci UDV305 and UDV737 linked with downy mildew-resistant gene Rpv3*

\begin{tabular}{|c|c|c|c|c|c|}
\hline & \multirow{3}{*}{$\begin{array}{l}\text { Origin } \\
\text { Rkatsitely } \times \text { Seyve Villard } 12-375\end{array}$} & \multirow{2}{*}{\multicolumn{2}{|c|}{$\begin{array}{l}\text { UDV305 } \\
\text { Allele size, bp }\end{array}$}} & \\
\hline & & & & \multicolumn{2}{|c|}{ UDV737 } \\
\hline & & 299 & 326 & 279 & 295 \\
\hline $\begin{array}{l}\text { Species (variety) } \\
\text { Dunavski lazur } \\
\text { Noah }\end{array}$ & \multirow{2}{*}{$\begin{array}{l}\text { Vitis riparia } \times \text { Vitis labrusca } \\
\text { Seibel' } 6468 \times \text { Seibel' } 6905\end{array}$} & 321 & 0 & 271 & 312 \\
\hline Seyve Villrd 12-375 & & 299 & 361 & 279 & 299 \\
\hline Dekabrskiy & Korna niagra $\times$ Seyve Villard 12-375 & \multicolumn{2}{|l|}{299} & 279 & 285 \\
\hline Dunavska gymza & (Mavrud $\times$ Pinot noir) $\times$ Seyve Villard 12-375 & \multicolumn{2}{|l|}{299} & 279 & 293 \\
\hline Original & Damasskaya roza $\times$ Seyve Villard 20-365 & 299 & 322 & 279 & \\
\hline Talisman & Frumoassa alba $\times$ Vostorg & 299 & 326 & 279 & 295 \\
\hline Kutuzovskiy & Moldavskiy $\times$ Seyve Villard 20-365 & \multicolumn{2}{|l|}{299} & 279 & 285 \\
\hline Kodryanka & Moldova $\times$ Marshalskiy & \multicolumn{2}{|l|}{299} & 279 & 285 \\
\hline Rysbol & Seyve Villard 12-375 $\times$ Sverkhranniy bessemyanniy & \multicolumn{2}{|l|}{299} & 279 & \\
\hline Storgoziya & $($ Mavrud $\times$ Pinot noir $) \times$ Seyve Villard $12-375$ & \multicolumn{2}{|l|}{299} & 279 & 295 \\
\hline R65 & Zala dyoengye $\times($ Gloria $\times$ Koroleva vinogradnikov $) \times$ Muscat zimniy & \multicolumn{2}{|l|}{299} & 279 & 289 \\
\hline Kishmish 342 & Seyve Villard $12-375 \times$ Perlette & 299 & 342 & 279 & \\
\hline Srebrostruy & Rkatsitely $\times$ Seyve Villard & 299 & 326 & 279 & 295 \\
\hline $\mathrm{VIII}-2-48$ & Moldova $\times\{$ Pobeda $\times[$ Katta-Kurgan $\times($ Kishmish rozoviy $\times$ Kishmish beliy) $]\}$ & \multicolumn{2}{|l|}{299} & \multicolumn{2}{|l|}{279} \\
\hline Armalaga & (Armlong $\times$ Malaga) & 321 & 334 & 271 & 312 \\
\hline Poliuks & Oberlen 595 (V. riparia $\times$ Game cherniy) $\times$ Foster white seedling & 229 & 321 & 312 & \\
\hline Podarok Magaracha & Rkatsitely $\times$ Magarach 2-57-72 & \multicolumn{2}{|l|}{321} & 297 & 312 \\
\hline Melody & Seyval blanc $\times$ Geneva white 5 (Pinot blanc $\times$ Ontario) & \multicolumn{2}{|l|}{0} & \multicolumn{2}{|l|}{271} \\
\hline Vesta & (Avgusta $\times$ V. amurensis $) \times($ Kentavr magarachskiy $\times$ Levokumskiy $)$ & 231 & 285 & 293 & 297 \\
\hline B 7-2 & Vitis vinifera $\times$ Vitis labrusca & \multicolumn{2}{|l|}{0} & 295 & 312 \\
\hline Doyna & Korna niagra × (Cabernet Sauvignon × Seyve Villard 23-657) & \multicolumn{2}{|l|}{290} & 279 & 285 \\
\hline Yalovenskiy Stoloviy & Ichkimar $\times$ Seyve Villard 20-366 & \multicolumn{2}{|l|}{299} & 281 & 295 \\
\hline Agadai & Local cultivar of Dagestan Vitis vinifera & \multicolumn{2}{|l|}{326} & 289 & 295 \\
\hline Alfa & Vitis vinifera $\times$ Vitis riparia & \multicolumn{2}{|l|}{296} & 285 & 303 \\
\hline Antaris & Saperavi $\times$ Tsimlyanskiy cherniy & 326 & & 301 & 295 \\
\hline Granatoviy & Saperavi $\times$ Cabernet Sauvignon & 254 & & 283 & 285 \\
\hline Golubok & Severniy $\times($ Vishnyoviy + Odesskiy ranniy $+1-17-54)$ & 322 & & 285 & 295 \\
\hline Dmitriy & Varousset $\times$ Granatoviy & 254 & & 285 & 295 \\
\hline Dostoyniy & Phillokseroustoychiviy Dzhemete $\times$ Muscat Gamburg & 320 & & 293 & 295 \\
\hline Krasnostop AZOS & Phillokseroustoychiviy Dzhemete $\times$ Krasnostop anapskiy & 320 & & 293 & 295 \\
\hline Murometc & Severniy $\times$ Pobeda & 342 & & 285 & \\
\hline Pomoriyski biser & Misket cherven $\times$ Seyve Villard 12-375 & 300 & & 293 & 301 \\
\hline Cvetochniy & Severniy $\times$ pollen of Muscat cultivars & 322 & 333 & 285 & \\
\hline Fioletoviy ranniy & Severniy $\times$ Muscat Gamburg & 300 & & 293 & 301 \\
\hline
\end{tabular}

* Data for the identified alleles are presented in a way chosen by G. Di Gaspero et al. (2012). 


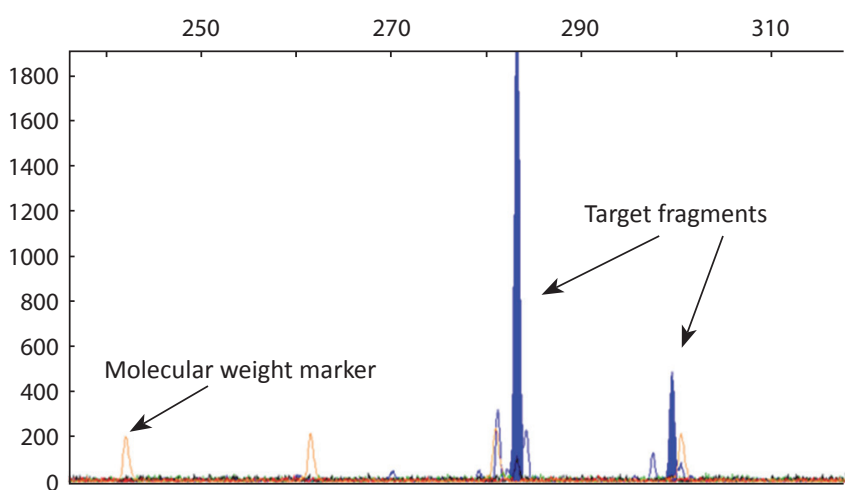

Visualization of the results of PCR - product fragment analysis with the UDV737 marker of the Storgoziya cultivar.

Seyve Villard 12-375. These were cultivars Dekabrskiy, Dunavska gymza, Rusbol, Storgoziya, Kishmish 342, and Srebrostruy. The Seyve Villard series are complex interspecies hybrids that are often used in grapevine breeding as resistance donors, and Seyve Villard 12-375 is one of the most known hybrids in the series that carry the geneplasm of $V$. vinifera, $V$. labrusca, V. rupestris, V. berlandieri, V. lincecumii. In the Kodryanka and $\mathrm{VIII}_{2}-2-48$ varieties, haplotype $R p v 3^{299-279}$ is inherited from parent variety Moldova (Guzal' kara $\times$ Seyve Villard 12-375), which means in this case Seyve Villard 12-375 has also served as a gene donor. According to the pedigree of R65 (Zala dyoengye (Seyve Villard 12-375 $\times$ Jemchug Saba $) \times($ Gloria $\times$ Koroleva vinogradnikov) $\times$ Muscat zimniy) the resistant allele was inherited from Seyve Villard 12-375. However, Seyve Villard $12-375$ is also considered one of the parents of the Pomoriyski biser variety, which carries no Rpv3 gene haplotype making it resistant to downy mildew.

In the genotype of the Talisman cultivar, the resistant allele was inherited from the Frumoassa alba variety, whose parent is Seyve Villard 20-473. Seyve Villard 20-365 served as a gene donor in varieties Original and Kutuzovskiy.

It is considered that resistant haplotype $R p v 3^{\text {null-271 initially }}$ originated from either $V$. labrusca or $V$. riparia. This is the haplotype we identified in American variety Melody. In the beginning, when analyzing its pedigree (Seyval blanc $\times$ Geneva white 5 (Pinot blanc $\times$ Ontario)) for its inclusion as a potential gene donor we assumed Seyval blanc (another name of Seyve Villard 5-276) to be the resistivity donor since its genetic formula contained $V$. rupestris and $V$. aestivalis. However, if we assume that $R p v 3^{\text {null-271 }}$ is inherited either from $V$. labrusca or from $V$. riparia, the indicated resistance allele in Melody can be inherited from Ontario (25\% V. vinifera $+75 \%$ V.labrusca)

Haplotype $R p v 3^{321-312}$ was identified in cultivars Armalaga, Poliuks and Podarok Magaracha. The published data indicate the source of this resistant haplotype to be either V. labrusca or $V$. riparia. In variety Armalaga, $R p v 3^{321-312}$ was inherited from $V$. labrusca, and in Poliuks - from $V$. riparia, which is confirmed by their pedigrees. Meanwhile, the pedigree of Podarok Magaracha remains an open issue. One of the parent varieties it inherited its mildew resistance from was probably Magarach 2-57-72 (Mtsvane $\times$ Sochinskiy cherniy). The
Sochinsky cherniy first discovered by P.Ya. Golodriga in the outskirts of Sochi has been lost and its exact genetic origin remains unknown, but its high resistance to fungal pathogens it transfers to its descendants makes it possible to classify it as an interspecies hybrid. The data we collected during the study allow us to assume that the pedigree of this species included either $V$. labrusca or $V$. riparia.

\section{Conclusion}

The presented study analyzed 35 vine genotypes of different origin to identify the presence of downy mildew-resistant gene $R p v 3$ using DNA markers UDV305 and UDV737. The analysis identified the Rpv3 gene in 19 grapevine cultivars, including 3 varieties, in which the presence of the gene had been confirmed earlier. The abovementioned markers allow one to identify a certain haplotype of the Rpv3 gene. That way, for the first time, haplotype $R p v 3^{299-279}$ has been detected in 12 interspecies varieties; Rpv3 $3^{321-312}$ - in three varieties; and $R p v 3^{\text {null-271 }}$ - in one variety. For the first time, the presence of the Rpv3 gene has been confirmed for such grapevine cultivars as Dekabrskiy, Dunavska gymza, Original, Talisman, Kutuzovskiy, Kodryanka, Rusbol, Storgoziya, R65, Kishmish 342, Srebrostruy, VIII-2-48, Armalaga, Poliuks, Podarok Magaracha and Melody. All the genotypes with Rpv3 are characterized by high or increased level of downy mildew resistance, which has been confirmed by the results of perennial observations (Petrov, Talash, 2010; Troshin, Radchevsky, 2010). The performed DNA analyses has also allowed us to assume that the parent varieties of Podarok Magaracha, whose pedigree remains unclear, are interspecies varieties carrying the geneplasm of either $V$. labrusca or V.riparia.

The results obtained can be used for selection of initial varieties to breed cultivars resistant to downy mildew.

\section{Acknowledgements}

The study was carried out with the financial support from Russian Foundation for Basic Research and from the Administration of Krasnodar Region (grant No. 16-44-230314 p_a).

\section{Conflict of interest}

The authors declare no conflict of interest.

\section{References}

Alleweldt G., Possingham J.V. Progress in grapevine breeding. Theor. Appl. Genet. 1988:75:669-673.

Bellin D., Peressotti E., Merdinoglu D., Wiedemann-Merdinoglu S., Adam-Blondon A.F., Cipriani G., Di Gaspero G. Resistance to Plasmopara viticola in grapevine "Bianca" is controlled by a major dominant gene causing localised necrosis at the infection site. Theor. Appl. Genet. 2009;120(1):163-176. DOI 10.1007/s00122-009-1167-2.

Di Gaspero G., Copetti D., Coleman C., Castellarin S.D., Eibach R., Kozma P., Lacombe T., Gambetta G., Zvyagin A., Cindrić P., Kovács L., Morgante M., Testolin R. Selective sweep at the Rpv3 locus during grapevine breeding for downy mildew resistance. Theor. Appl. Genet. 2012;124:227-286. DOI 10.1007/s00122-0111703-8.

Eibach R., Zyprian E., Welter L., Töpfer R. The use of molecular markers for pyramiding resistance genes in grapevine breeding. Vitis. 2007;46:120-124. 
International Variety Catalogue VIVC. Julius Kuhn-Institut. http:// www.vivc.de.

Ochssner I., Hausmann L., Töpfer R. Rpv14, a new genetic source for Plasmopara viticola resistance conferred by Vitis cinerea. Vitis: J. Grapevine Res. 2016;55(2):79-81. DOI 10.5073/vitis.2016.55.79-81.

Petrov V.S., Talash A.I. Pest Resistance in Grape Varieties. Krasnodar, 2010. (in Russian)

Rogers S.O., Bendich A.J. Extraction of DNA from milligram amounts of fresh, herbarium and mummified plant tissues. Plant Mol. Biol. 1985;19(1):69-76.

Schwander F., Eibach R., Fechter I., Hausmann L., Zyprian E., Töpfer R. Rpv10: a new locus from the Asian Vitis gene pool for pyramiding downy mildew resistance loci in grapevine. Theor. Appl. Genet. 2012;124(1):163-176. DOI 10.1007/s00122-011-1695-4

Talash A.I. Grades of pest harmfulness in vineyards. Plodovodstvo i Vinogradarstvo Yuga Rossii $=$ Fruit Growing and Viticulture of South Russia. 2010;4(3):24-29. (in Russian)
Troshin L.P., Radchevskiy P.P. Grapevine: Illustrated Catalog. Released, Promising, and Mass-Production Varieties. Rostov n/D., 2010. (in Russian)

Venuti S., Copetti D., Foria S., Falginella L., Hoffmann S., Bellin D., Di Gaspero G. Historical introgression of the downy mildew resistance gene Rpv12 from the Asian species Vitis amurensis into grapevine varieties. PLoS ONE. 2013;8(4):1-7. DOI 10.1371/journal. pone.0061228.

Wan Y., Schwaninger H., He P., Wang Y. Comparison of resistance to powdery mildew and downy mildew in Chinese wild grapes. Vitis. 2007;46:132-136.

Zini E., Raffeiner M., Di Gaspero G., Eibach R., Grando M.S., Letschka T. Applying a defined set of molecular markers to improve selection of resistant grapevine accessions. Acta Horticulturae. 2014; 1082:73-78. DOI 10.17660/ActaHortic.2015.1082.9. 